\title{
Nexus between Bank Credit and Economic Growth in Nigeria: Evidence from VEC Model
}

\author{
Garba Salisu Balago \\ Department of Accounting, Nasarawa State University, Keffi, Nigeria \\ Email: gsbalago@yahoo.co.uk
}

Received 2 August 2014; revised 30 September 2014; accepted 1 November 2014

Copyright (C) 2014 by author and OALib.

This work is licensed under the Creative Commons Attribution International License (CC BY). http://creativecommons.org/licenses/by/4.0/

(c) (i) Open Access

\section{Abstract}

The study examines the relationship between bank credit and economic growth in Nigeria by considering the total bank credit extended to the production sector (which comprises manufacturing, agriculture, fishery and forestry, mining and quarrying, real estate and construction), general commerce sector (comprising: bills discounted, domestic trade, exports and imports) and services sector (comprising: public utilities, transport and communication, credit to financial institutions). Time series data from 1983-2012 were fitted into the regression equation using various econometric techniques such as stationarity test using Augmented Dickey Fuller (ADF) and Johansen Multivariate Co-Integration Test. Ordinary Least Square Regression (OLS) and VEC Models were used to analyse the relationship between the independent variables (total credits to production, general commerce and services sectors) and dependent variable (real gross domestic product). The result of the OLS shows that total bank credit to production, general commerce and services sectors has a positive relationship with the gross domestic product. Similarly, the VEC model result shows that causality runs from bank credit to the GDP. This result is consistent with a number of earlier studies reviewed in the literature that find causality running from bank credit to gross domestic product.

\section{Keywords}

Bank Credit, Economic Growth, Nexus, Causality

Subject Areas: Accounting, Business Finance and Investment

\section{Introduction}

Theories of finance and economic growth suggest that the financial functions provided by banks (and other financial intermediaries) are important in promoting economic growth. Empirical research strongly supports the view that banks promote economic growth at the firm, industry and country levels. The recent literature also 
highlights that not only is the aggregate size of financial intermediaries important for economic growth, but also the institutional framework of the banking sector can significantly affect economic growth [1].

There is a belief that efficient allocation of savings through identification and funding of businesses offers the best chances of a successful production processes, product development and innovation that contribute positively to the macro-economy. Several scholars like McKinnon and Shaw [2], King and Levine [3] supported the above postulation on the importance of banks to the growth of the economy.

While reporting on the works of various authors on financial intermediation, Ndebbio [4] posited that the economic development of any nation greatly depended on financial intermediation by banks just as he observed that stagnation in output of any country, especially the less developed ones, was often blamed on shallow finance. However, there are divided opinions on the roles of banks in economic development. While some schools of thought like Adelman and Morris [5], Goldsmith [6] among others are of the opinion that development in the financial institutions (banks) precedes and hence plays a significant role in economic development; a contrary school comprising, among others like Patrick [7] sees finance as passive in the growth process.

In order to examine the relationship that exists between credit and economic growth, previous studies have used several analytical approaches. These include cross country growth regression used by King \& Levine [8]; panel techniques used by Rioja \& Valev [9] and time-series used by Demetriades \& Hussein [10]. However, in the opinion of Demetriades \& Andrianova [11], it would be difficult to draw up any reliable policy implications from cross-country or panel regressions, and those conclusions that we may draw from time-series studies for individual countries cannot be generalised. In essence, time-series is more applicable for single country analysis; hence this study intends to use time-series method of estimation following the methods used by Ghirmay [12], Demetriades \& Hussein [10]. This according to Demetriades \& Andrianova [11] allows the use of appropriate statistical procedures, such as co-integration to test longevity of relationships; they also allow the use of statistical procedures that can shed light on the causality between two or more variables in both the long run and the short run.

In their contributions to the bank-development debate, McKinnon (1973) [13] and Shaw (1973) [14], in a financial repression hypothesis, argue that the performance of banks in growth process is affected by the regulation of the system. According to Akpan (2004) [15], the Financial Repression Hypothesis believes in a financial market driven by the forces of demand and supply, hence, with a free interest rate, depositors earn more interest on their deposits and are encouraged to make more deposits. This in turn leads to capital formation and consequently economic growth through the multiplier effect. It is on the basis of this divergence of opinions that it is necessary to examine the relationship between banks and economic growth in Nigeria. A successful outcome of the research will assist policy makers, particularly the Central Bank of Nigeria (CBN) in developing appropriate policies for banking sector to influence credit to sectors that have a direct impact on the GDP. This will translate to more output and employment generations with the positive impact on economic growth.

\subsection{Research Questions}

The link between bank credit and economic growth has been widely debated in economic literatures. Many researchers are of the view that there still exists some great dichotomy in the role of financial intermediaries at facilitating sustainability of economic growth in the long term. Earlier studies by Schumpeter (1911) [16], Gurley and Shaw (1955) [17], suggested that banks played a pivotal role in economic development because they chose which firms get to use societal savings. Later studies like Levine and Zervos (1996) [18] contested the above position by arguing that financial system did not promote economic growth rather the institutions responded to developments in the real sector within the economy. The questions this study intends to attempt certain answers to are:

1) Is there any relationship between bank credit and economic growth in Nigeria?

2) Does bank credit causes economic growth or economic growth causes bank credit?

\subsection{Objectives of the Study}

The broad objective of this study is to investigate the relationship between bank credit and economic growth. Specifically, this study will:

1) Examine the relationship between bank credit and gross domestic product.

2) Determine the direction of causality between bank credit in Nigeria and economic growth: Whether bank 
credit induces growth or only responds to the growth process in Nigeria.

\subsection{Hypotheses}

The following hypotheses are formulated in line with the research objectives.

\section{Hypothesis 1}

$\mathrm{H}_{\mathrm{o} 1}$ : There is no significant relationship between bank credit and economic growth in Nigeria.

$\mathrm{H}_{\mathrm{A} 1}$ : There is a significant relationship between bank credit and economic growth in Nigeria.

Hypothesis 2

$\mathrm{H}_{02.1}$ : There is no significant causal relationship between credit to production sector and real gross domestic product in Nigeria.

$\mathrm{H}_{\mathrm{A} 2.1}$ : There is a significant causal relationship between credit to production sector and real gross domestic product in Nigeria.

$\mathrm{H}_{02.2}$ : There is no significant causal relationship between credit to general commerce sector and real gross domestic product in Nigeria.

$\mathrm{H}_{\mathrm{A} 2.2}$ : There is a significant causal relationship between credit to general commerce sector and real gross domestic product in Nigeria.

$\mathrm{H}_{02.3}$ : There is no significant causal relationship between credit to service sector and real gross domestic product in Nigeria.

$\mathrm{H}_{\mathrm{A} 2.3}$ : There is a significant causal relationship between credit to service sector and real gross domestic product in Nigeria.

The rest of the paper is organized as follows: The immediate section provides the literature; Section 3 is the methodology; Section 4 contains results and discussion while Section 5 reports conclusion and recommendation.

\section{Literature Review}

Financial intermediaries serve as media for savings-investment process. One fundamental question is: Will the development of financial intermediaries influence economic growth? A vast empirical literature on the issue exists with varying and often contradicting views. This resulted in the formation of four major hypotheses in the finance-growth literature. In order to shed more light on these hypotheses, the study categorise the literature into theoretical and empirical variant of literatures.

\subsection{Theoretical Literature}

The nexus between the financial sector and the real sector received less attention from economists until the early twentieth century when the German economist Schumpeter (1952) [19] observed that, the financial market, especially the banks, play a significant role in the growth of the real economy. He argued that, banks mobilise and channel funds efficiently which, provide the necessary credit to entrepreneurs to finance investment in physical capital, adopt new production techniques, thereby, spurring technological innovation and setting the stage for a creative production process. According to Allen and Ndikumana (1998) [20]; King and Levine, (1993) [8], all these sum up to economic growth. This view implies that financial development causes economic growth, hence, Schumpeter was seen as the pioneer of supply-leading hypothesis of the finance-growth relationship. However, his analysis was criticized in the academic world for lacking in analytical basis.

The supply-leading hypothesis was logically contested by McKinnon (1973) [13] and Shaw (1973) [14] in their financial repression theory. They argued that economic growth is hindered in a repressed financial system which is, characterized by interest rate ceiling, directed credit allocation policies and high reserve requirement. According to the duo, this phenomenon leads to low level of saving, credit rationing and low investment. Therefore, they proposed financial liberalization which will allow for a rise in real rate of interest thereby, elevating financial savings. The increase in savings in relation to real economic activity will lead to increase in financial intermediation. This will in turn lead to increase in productive investment and economic growth (Ayadi, Adegbite and Ayadi, 2008) [21]. The policy implication of this viewpoint is the need to liberalise the financial system to enhance financial intermediation, which will result in high economic growth. However, the failure to record meaningful success by most developing countries that have implemented these policies raises the questions as to the validity of the hypothesis. 
Nigeria being a case study of this study is not an exception to findings, this is because the financial sector was liberalized through the adjustment programme implemented in 1986, yet the financial sector failed in its primary function of financial intermediation and promoting of growth of the real economy. Confirming this, Hesse (2007) [22] reported that relative to the pre-deregulated period, financial intermediation never took off and even declined in the 1980s and 1990s and that Nigeria's financial sector up to 2004 was still characterized by a high degree of fragmentation and low levels of financial intermediation.

The above realities prompted some economists to come up with the demand-following hypothesis pioneered by Robinson (1952) [23] who asserts that where finance follows growth leads. This hypothesis regards financial development as endogenously determined by the need of real economy, meaning that as the economy growths the demand for financial services follows.

The mutual dependence or interdependence hypothesis tries to balance the two view points above; it postulated that the causality between financial development and economic growth is reciprocal. This view was championed by Patrick (1966) [24]. This view states that underdeveloped countries gain significantly in real terms from developing their financial sectors (supply-leading), whereas in highly developed economies finance becomes increasingly demand-followed. Given that many empirical studies (e.g. Esso, 2010) [25] found economic growth to be leading financial development in many developing countries, the hypothesis does not validate the postulate. These contrasting views on the finance-growth nexus lead to the extreme neutrality hypothesis; it contends that financial sector development is not significantly related to real growth. The view is expressed most prominently by Lucas (1988) [26] who observed that the finance-growth relationship is unnecessarily over-stressed. The neo-classical assumption of perfect information and zero transaction costs form the basis of his argument. In such a situation, financial institutions are irrelevant and firms will be indifferent as to the source of finance; internal or external (Blum, et al., 2002) [27].

The neutrality hypothesis, however, has no sound footing, as in real life, transaction costs can never be zero; firms have to incur cost when borrowing from the financial market and if they excessively use internal financing they will declare fewer dividends and their share price may fall. Moreover, recent financial crises and the collapse of many large corporations are suggestive of the existence of information asymmetry especially in the financial sector. These views and counter views on the finance-growth relationship are pointing to the fact that the issue is still inconclusive and, therefore, more studies are still needed especially on developing countries. The current study on financial development in the form of banking sector credit and output growth in Nigeria is one of such efforts geared towards resolving the issue. At this point it is worth noting that the above hypotheses were more or less based on intuition; they are not based on any growth model, therefore, their analysis is rather one sided. To this end theoretical studies which are based on endogenous growth model are reviewed below.

To begin with, a paradigm was presented by Greenwood and Jovanovic (1990) [28] in which both the extent of financial intermediation and the rate of economic growth are endogenously determined. They showed that financial intermediation promotes growth because it allows a higher rate of return to be earned on capital, and growth in turn provides the means to implement costly financial structures. Thus financial intermediation and economic growth are inextricably linked. Growth provided the wherewithal to develop financial structure, while financial structure in turn allowed for higher growth since investment could be more efficiently undertaken. This finding is consistent with mutual dependence hypothesis.

Taking into account the behaviour of economic agents, Bencivenga and Smith (1991) [29] developed endogenous growth model with multiple assets. They showed that prior to the introduction of financial intermediation, agents who face random future liquidity needs accumulate capital and a liquid, but unproductive asset. However, upon the introduction of financial intermediation the composition of savings shifts toward capital, causing intermediation to be growth promoting. They further argued that generally financial intermediaries reduce socially unnecessary capital liquidation, again tending to promote growth. This implies that by enhancing liquidity and mitigating idiosyncratic risk through risk diversification and pooling, the development of financial intermediaries, results in a reduction of household unproductive reserve of liquid assets. Consequently, funds are channeled towards illiquid but more productive activities, and a developed financial intermediation process at this stage can highly contributes to economic growth. This lends credence to the supply-leading hypothesis.

Similarly, using endogenous growth model, Pagano (1993) [30], revealed that financial intermediation can affect economic growth positively by acting on the savings rate, on the fraction of saving channelled to investment, or on the social marginal productivity of investment. Nonetheless, he outlined some exceptions in which improvements in risk-sharing and in the household credit market may decrease the saving rate and hence the 
growth rate. Therefore, financial development is too generic a term; to use in measuring the impact on growth, one must specify the particular financial market concerned. Going by this, the focus of this study on banking sector credit in Nigeria is consistent with agreed norm and logic.

\subsection{Empirical Literature}

Azege (2004) [31] examined the empirical relationship between the level of development by financial intermediaries and growth. The study employed data on aggregate deposit money bank credit over time and gross domestic product to establish that a moderate positive relationship exist between financial deepening and economic growth. He concluded that the development of financial intermediary institutions in Nigeria is fundamental for overall economic growth.

Agu (2008) [32] in his effort to ascertain the direction of causality between "bank-based" financial deepening variables and economic growth in Nigeria, found that financial deepening and economic growth were positively co-integrated and that there was only one co-integrating vector indicating a stable and sustainable long-run equilibrium relationship between "bank-based" financial deepening variables and economic growth.

Fadare (2010) [33] empirically identifies the effect of banking sector reforms on economic growth in Nigeria by using the data 1999-2009. Variables used for the study are interest rate margins, parallel market premiums, total banking sector credit to the private sector, inflation rate, inflation rate lagged by one year, size of banking sector capital and cash reserve ratios. Results indicate that the relationship between economic growth and other exogenous variables of interest rate margins, parallel market premiums, total banking sector credit to the private sector, inflation rate and cash reserve ratio is negative and insignificant.

Dele (2007) [34] investigates the banking reform in Nigeria from the perspective of Soludo's reform by using the data of 40 commercial and merchant banks. The variables used for the study are lending, interest rate and the foreign exchange policy. The study uses the descriptive statistics to test its hypothesis. The result indicates that recapitalization has impacted significantly to the banking services and to the growth of economy as whole.

Khatib et al. (1999) [35] investigate the relationship between commercial banking performance and economic growth in Qatar. The study used the variables of bank profit, GDP, foreign interest rates, government revenues, government expenditures, banks equity, regression analysis model and data for the period from 1996 to 1997. The results found that predictions through variables and model are highly effective and responsible for economic growth.

Kayode et al. (2010) [36] investigates the effect of bank lending and economic growth on the manufacturing output in Nigeria using the times series data covering a period of 36 years (1973 to 2009). The technique used for the analysis and the model was co-integration and vector error correction model (VECM) techniques. The empirical outcomes of the study show that production volume in manufacturing and bank rate of lending loans significantly affects manufacturing output in Nigeria. However, the relationship between manufacturing output and economic growth could not be established in the country.

Chang, Jia and Wang (2010) [37] examine bank fund reallocation and regional economic growth based on 1991-2005 provincial-level data of four state-owned commercial banks of China. They found no correlation at the regional level between fund reallocation and bank loans on the one hand and economic growth on the other.

Mixed results was found by Esso (2010) [25] in a study that re-examine the co-integrating and causal relationship between financial development (ratio of private credit to GDP) and economic growth in the Economic Community of West African States (ECOWAS) over the period 1960-2005. The results show that there is a long-run relationship between financial development and economic growth but with different direction of causality. In Ghana and Mali financial development leads economic growth while growth causes finance in Burkina Faso, Cote d'Ivoire and Sierra Leone, and bidirectional causality is found in Cape Verde and Liberia. The policy implication is that Cape Verde, Ghana and Mali should give policy priority to financial reform while Burkina Faso, Cote d'Ivoire and Sierra Leone should promote economic growth. This negates the view that stage of development determine the causal relationship between financial development as these countries are about at the same stage of development, yet they show inconsistent causality, the fact that the study used a single measure of financial development (ratio of private credit to GDP) might have limited the chances of revealing more relationship between finance and development in these countries.

Fadare, (2010) [33] explore the effect of banking sector reforms on economic growth in Nigeria over the period 1999-2009. Using the ordinary least square regression technique, he found that interest rate margins, paral- 
lel market premiums, total banking sector credit to the private sector, inflation rate, inflation rate lagged by one year, size of banking sector capital and cash reserve ratios account for a very high proportion of the variation in economic growth in Nigeria.

Demetriades and James (2011) [38] in a study of eighteen Sub-Saharan African countries reports that the link between credit and growth is altogether absent while finance does not lead growth in the long run. Similar views are reported by Estrada et al. (2010) [39] and Kumar (2011) [40].

Oluitan (2012) [41], assesses the significance of real bank credit in stimulating real output growth in the case of Nigeria. The study observes that credit Granger causes output.

Zhang, Wang and Wang (2012) [42] examine the relationship between financial intermediation and economic growth in China, using data from 286 Chinese cities over the period 2001-2006. Their results suggest that traditionally used indicators of financial development are generally positively associated with economic growth after controlling for many factors associated with growth.

Emmanuel and Adegboyega (2014) [43] examine the relationship between banks and economic growth in Nigeria. The study adopts linear regression function and specifies that the level of real gross domestic product, which is a measure of economic activity, is a function of banks credit to the economy which is a measure of the contribution of banks. The results of the models estimated show that banks have positive impacts on economic growth in Nigeria.

\section{Methodology}

The study relies mainly on published time series data obtained from CBN statistical bulletin, Volume 23 of December 2012. The data covers gross domestic product (GDP) as the dependent variable and the values of bank credits as independent variables based on the CBN sectorial classification of loans viz:

1) Production sector: consisting of agriculture forestry and fishery, manufacturing, mining and quarrying and real estate and construction.

2) General commerce sector: consisting of bills discounted, domestic trade, export and import.

3) Services sector: consisting of public utilities, transport and communication and credit to financial institutions.

The data cover a period of 30 years running from 1983 to 2012. The variables were subjected to econometric tests using EViews Version 8.0.

\subsection{The Model}

Hypothesis 1 is tested using ordinary least square (OLS) multiple regression model at 5\% significant level while hypothesis 2 is tested using vector error correction model. This study is interested in the long run and predictive effect of bank credit on real GDP.

\subsubsection{Ordinary Least Square Multiple Regression Model}

The linear regression equation for this model for hypothesis 1 is given as:

Model 1: $\operatorname{RGDP}_{i}=\alpha_{1}+\beta_{1} \mathrm{CPS}_{i}+\beta_{2} \mathrm{CGCS}_{i}+\beta_{3} \mathrm{CSS}_{i}+\varepsilon_{i}$

where $\mathrm{RGDP}_{i}$ is the real GDP for the sample period, CPS ${ }_{i}$ represent the credit to production's contribution to gross domestic product, CGCS $_{i}$ represent the credit to general commerce's contribution to gross domestic product, $\mathrm{CSS}_{i}$ represent the credit to services' contribution to gross domestic product, $\varepsilon_{i}$ represents the "noise" or error term; $\alpha_{i}$ and $\beta_{1}$ represent the slope and coefficient of regression. The coefficient of regression, $\beta_{i}, \beta_{2}$ and $\beta_{3}$ indicate how a unit change in the independent variable (credit to production sector, general commerce sector and services sector) affects the dependent variable (gross domestic product). The error, $\varepsilon_{i}$, is incorporated in the equation to cater for other factors that may influence GDP.

Hypothesis 2 is tested using vector error correction model. Various econometric techniques such as test of stationarity properties of the time series data using Augmented Dickey-Fuller (ADF) and co-integration test using Johansen Multivariate were applied.

\subsubsection{Vector Error Correction (VEC) Model \\ Model 2.1: RGDP and credit to production sector}




$$
\begin{aligned}
& \Delta \operatorname{lnRGDP}=\alpha_{0}+\alpha_{1} \Delta \operatorname{lnRGDP}_{t-1}+\alpha_{2} \Delta \operatorname{lnCPS}_{t-1}+\mathrm{Ec}_{t-1}+\varepsilon_{t 1} \\
& \Delta \operatorname{lnCPS}=\beta_{0}+\beta_{1} \Delta \operatorname{lnCPS}_{t-1}+\beta_{2} \Delta \operatorname{lnRGDP}_{t-1}+\mathrm{Ec}_{t-1}+\varepsilon_{t 2}
\end{aligned}
$$

\section{Model 2.2: RGDP and credit to general commerce sector}

$$
\begin{aligned}
& \Delta \operatorname{lnRGDP}=\alpha_{0}+\alpha_{1} \Delta \operatorname{lnRGDP}_{t-1}+\alpha_{2} \Delta \operatorname{lnCGCS}_{t-1}+\mathrm{Ec}_{t-1}+\varepsilon_{t 1} \\
& \Delta \operatorname{lnCGCS}=\beta_{0}+\beta_{1} \Delta \operatorname{lnCGCS}_{t-1}+\beta_{2} \Delta \operatorname{lnRGDP}_{t-1}+\mathrm{Ec}_{t-1}+\varepsilon_{t 2}
\end{aligned}
$$

\section{Model 2.3: RGDP and credit to services sector}

$$
\begin{gathered}
\Delta \operatorname{lnRGDP}=\alpha_{0}+\alpha_{1} \Delta \operatorname{lnRGDP}_{t-1}+\alpha_{2} \Delta \operatorname{lnCSS}_{t-1}+\mathrm{Ec}_{t-1}+\varepsilon_{t 1} \\
\Delta \operatorname{lnCSS}=\beta_{0}+\beta_{1} \Delta \operatorname{lnCSS}_{t-1}+\beta_{2} \Delta \operatorname{lnRGDP}_{t-1}+\mathrm{Ec}_{t-1}+\varepsilon_{t 2}
\end{gathered}
$$

where $\ln$ is natural logarithms, CPS is the aggregate bank credit to production sector for the sample period. RGDP is real gross domestic product, $\alpha$ is a constant, $\beta_{i}$ is the coefficient of regression, Ec is the error correction term, $\varepsilon$ is the error term and $t$ is time. The error term, $\varepsilon$ is incorporated in the equation to cater for other factors that may influence the variables. CGSS is the bank credit to general commerce sector while CSS represent the bank credit to services sector. In order to estimate the models, a statiscal package, EViews 8.0 econometric software is used.

\section{Result and Discussion}

The nexus between bank credit and economic growth is examined in this section.

\subsection{Hypothesis 1: Test of Relationship Using OLS}

The result for hypothesis 1 is presented in Table 1 while the test for hypothesis 2 is presented in Tables 2-6 below.

Decision criteria:

Hypothesis $\mathrm{H}_{01}$ would be rejected if the standard errors of the independent variables (CPS, CGCS and CSS) are less than half their estimated (coefficients), i.e., where the standard error of each of the independent variable is less than half its coefficient (coefficient divided by 2).

Table 1. Ordinary least square multiple regression results.

\begin{tabular}{ccccc}
\hline Variable & Coefficient & Std. error & t-statistic & Prob. \\
\hline CPS & 0.004547 & 0.000383 & 0.184291 & 0.7661 \\
CGCS & 0.002932 & 0.000477 & 1.372449 & 0.1841 \\
CSS & 0.208041 & 0.100031 & 4.514029 & 0.0003 \\
C & 259571.1 & 18352.59 & 12.89123 & 0.0000 \\
R-squared & 0.790649 & Mean dependent var & 407127.8 \\
Adjusted R-squared & 0.710145 & S.D. dependent var & 135423.8 \\
Sum squared resid & $5.02 \mathrm{E}+10$ & Schwarz criterion & 25.05707 \\
Durbin-Watson stat & 0.275862 & Prob (F-statistic) & 0.000000 \\
\hline
\end{tabular}

Source: Compiled from EViews 8.0.

Table 2. ADF unit root tests.

\begin{tabular}{ccccc}
\hline Variables & ADF test statistics & Critical value & Lag & Stationarity \\
\hline CPS @ TREND & -2.493875 & -1.0521 & 2 & $\mathrm{I}(1)$ \\
CGCS @ TREND & -5.348860 & -2.0541 & 1 & $\mathrm{I}(1)$ \\
CSS @ TREND & 3.298211 & -3.0088 & 1 & $\mathrm{I}(0)$ \\
RGDP @ TREND & -2.382299 & -1.7352 & 2 & $\mathrm{I}(1)$ \\
\hline
\end{tabular}

Source: Compiled from appendix using EViews 8.0. 
Table 3. Johansen co-integration test.

\begin{tabular}{|c|c|c|c|c|}
\hline Variables & Max-Eigen statistic & Critical value & Trace statistic & Critical value \\
\hline RGDP AND CPS & 14.62999 & 12.07 & 14.07099 & 11.21 \\
\hline RGDP AND CGCS & 20.11873 & 12.07 & 22.84730 & 11.21 \\
\hline RGDP AND CSS & 18.16091 & 12.07 & 18.57377 & 11.21 \\
\hline \multicolumn{5}{|c|}{ Max-Eigen value test indicates 1 co-integrating equation(s) at the $5 \%$ level } \\
\hline \multicolumn{5}{|c|}{ Trace test indicates 1 co-integrating equation(s) at the 5\% level } \\
\hline \multicolumn{5}{|c|}{ Critical values are all at 5\% } \\
\hline
\end{tabular}

Source: Compiled from EViews 8.0 result.

Table 4. Vector error correction based causality test for RGDP and CPS.

\begin{tabular}{cccc}
\hline Model 2.1 & RGDP & CPS & Causality \\
\hline Standard error & 0.01154 & 1.14815 & Causality runs from CPS to RGDP \\
t-statistic & 0.20733 & 6.33713 & \\
\hline
\end{tabular}

Source: Compiled from EViews 8.0.

Table 5. Vector error correction based causality test for RGDP and CGCS.

\begin{tabular}{cccc}
\hline Model 2.3 & RGDP & CGCS & Causality \\
\hline Srandard error & 0.06333 & 11.0616 & Causality runs from CGCS to RGDP \\
t-statistic & -0.41531 & -2.15239 & \\
\hline
\end{tabular}

Source: Compiled from EViews 8.0 result.

Table 6. Vector error correction based causality test for RGDP and CSS.

\begin{tabular}{cccc}
\hline Model 2.2 & RGDP & CSS & Causality \\
\hline Srandard error & 0.13029 & 0.35433 & Causality runs from CSS to RGDP \\
t-statistic & 0.27143 & 3.00276 & \\
\hline
\end{tabular}

Source: Compiled from EViews 8.0.

The standard error measure the statistical reliability of the coefficient estimates-the larger the errors, the more statistical noise in the estimates. From the table above, the standard error of CPS is 0.000383 while that of CGCS and CSS are 0.000477and 0.100031 respectively which appears insignificant and shows that CPS, CGCS and CSS are statistically reliable to predict real GDP. From the above table, the standard error tests shows that all the standard errors are less than half their respective estimates (coefficients) meaning that hypothesis $\mathrm{H}_{01}$, should be rejected.

The least square multiple regression equation is:

$$
\mathbf{R G D P}=\mathbf{2 5 9 5 7 1 . 1}+0.004547 * \mathbf{C P S}+0.002932 * \mathbf{C G C S}+0.208041 * \mathbf{C S S}
$$

The equation shows $\alpha=259571.1$ which is the intercept. This is the base level of prediction when the CPS, CGCS and CSS are equal to zero. The coefficient of CPS, CGCS and CSS measures the how a unit of change in independent variable affects the dependent variable. From the results, a unit change in bank credit to production sector leads to about $0.45 \%$ increase in real GDP. While a unit change in bank credit to general commerce sector leads to $0.29 \%$ increase in real GDP and accordingly a unit change in bank credit to services sector leads to $20.80 \%$ increase in real GDP. This shows that there is a positive relationship between bank credit to Production sector, bank credit to general commerce sector, bank credit to services sector and the real GDP.

$\mathrm{R}$-squared $\left(\mathrm{R}^{2}\right)$ is the fraction of the variance of the dependent variable explained by the independent variable. In this result the $\mathrm{R}^{2}$ is about $79 \%$, meaning that about $79 \%$ of real GDP is explained by the CPS, CGCS and CSS.

Sum squared residual is a measure of error in using the estimated regression equation to estimate the values of the real GDP. The mean and standard deviation of real GDP is N407127.8 and 135423.8 million respectively. 


\subsection{Hypothesis 2: Test of Causal Relationship Using Vector Error Correction Model}

\subsubsection{Investigation of the Stationarity Properties of Data}

The properties of the time series data for the period of the study covering 1983-2012 was investigated in order to test its stationarity using the Augmented Dickey-Fuller (ADF) test statistics. The lag length was determined using Akaike's (1969) [44] and Schwartz's (1978) [45] Information criterion and Akaike's (1987) [46] final prediction error criterion. The number of lags used in ADF regressions was selected using Akaike Information Criterion (AIC).

ADF statistics with intercept are obtained by taking Akaike Information Criterion (AIC) into account.

Table 2 shows the ADF test results of the time series.

Decision criteria:

Variables at trend are stationary if their ADF test statistic is greater than their critical value in absolute terms. The results suggest that the null-hypothesis $\left(\mathrm{H}_{0}\right)$ of unit root can be rejected in the first difference, I(1) for CPS, CGCS and RGDP, while CSS can be rejected at level respectively. All the series (i.e. CPS, CGCS, CSS and RGDP) are stationary and therefore their regression will not be a spurious regression. They are all stationary at $5 \%$ critical value.

\subsubsection{Co-Integration Analysis}

Johansen's (1988) [47] multivariate co-integration test was used to determine if the variables are co-integrated. Co-integration analysis is necessary in all times series data so as to determine whether or not there is a long run relationship between two variables.

The results of the Johansen co-integration test are presented in Table 3.

The results of the co-integration analysis are in Table 3.

Decision criteria:

Two variables are co-integrated if both their Max-Eigen and trace statistic are greater than their respective critical values. The co-integration test results show that all the variables (CPS, CGCS, CSS and RGDP) have their Max-Eigen and trace statistic greater than their respective critical values, meaning that they are co-integrated. Since the variables are stationary, integrated of order one, and co-integrated, it shows that there is a long run relationship between the variables.

\subsubsection{Causality Test}

The causality test used is the vector error correction based causality test and the results are presented in Tables 4-6.

The above table presents the result of causality test between credit to production sector and real GDP.

1) Decision criteria

The direction of causality can be determined by comparing the $t$-statistic of the two variables. Causality runs from the variable with higher $t$-statistic to the variable with lower $t$-statistic.

From the above table it shows that causality runs from the CPS to the RGDP since the $t$-statistic of CPS is greater than that of the RGDP. This means that hypothesis $\mathrm{H}_{02.1}$ should be rejected and $\mathrm{H}_{\mathrm{A} 2.1}$ be accepted.

From the above table, using the decision criteria above, it shows that causality runs from the CGCS to the RGDP since the $t$-statistic of CGCS is greater than that of the RGDP, which means that hypothesis $\mathrm{H}_{02.2}$ should be rejected and $\mathrm{H}_{\mathrm{A} 2.2}$ be accepted.

From the above table, the result shows that causality runs from CSS to the RGDP since the $t$-statistic of CSS is greater than that of the RGDP and hence hypothesis $\mathrm{H}_{02.3}$ should be rejected and $\mathrm{H}_{\mathrm{A} 2.3}$ be accepted.

The various results of the test shows that causality runs from bank credit to production sector to the real GDP, causality runs from bank credit to general commerce sector to the real GDP and causality runs from bank credit to services sector to the real GDP.

2) Discussion of result

The preliminary tests of the data using statistical tools shows that they are stationary and co-integrated. This means that their combinations will not lead to spurious regression and there exist a long run relationship between the variables which can be sustained.

The ordinary least square multiple regression of RGDP with CPS, CGCS, and CSS was run to find if relationship exist between the bank credit to production sector and the real gross domestic product, the bank credit to general commerce sector and the real gross domestic product as well as between the bank credit to services 
sector and the real gross domestic product.

The result of the OLS shows that, there is positive relationship between each of the CPS, CGCS, CSS and RGDP. R-square which is the coefficient of variation shows that about 79 per cent of changes in real gross domestic product is explained by credit to production sector, credit to general commerce sector and credit to service sector while only 21 percent is explained by other factors? The standard errors for the independent variables are all insignificant. This shows that the independent variables are statistically reliable to predict the dependent variable, implying reliability of the results.

From the results, a unit change in bank credit to production sector leads to about $0.45 \%$ increase in real GDP. While a unit change in bank credit to general commerce sector leads to $0.29 \%$ increase in real GDP and accordingly a unit change in bank credit to services sector leads to $20.80 \%$ increase in real GDP.

The causality test between the variables which was conducted using vector error correction model shows that causality runs from the three independent variables (credit to production sector, credit to general commerce sector and credit to services sector) to the dependent variable (real GDP). This means that credit to production sector, credit to general commerce sector and credit to services sector causes real GDP. This shows that, bank credit does not respond to economic growth but rather it causes economic growth in Nigerian case. The findings lend credence to the demand-following hypothesis as argued by Schumpeter rather than supply-leading hypothesis as argued by McKinnon (1973) [13] and Shaw (1973) [14].

The policy implication of the above result is that, the current effort of the CBN to encourage banks to extend more credits to the production sector particularly, the Manufacturing, Agriculture and Fishery and Forestry sub-sectors as against other sectors like the service sector need to be re-evaluated. This is because while about $20.8 \%$ of the GDP is explained by the total bank credits to the services sector only about $0.45 \%$ of the GDP is explained by the total bank credit to the production sector. This might be due to the infrastructure decay in the country which significantly affects the sector and consequently its ability to utilize the credit for more production and employment generation.

The findings based on the data for the period 1983-2012 from both the OLS and the vector error correction models provide evidence, in support of earlier findings from studies both in Nigeria and other economies. The result is in line with some of the studies conducted within Nigeria like Onuorah \& Ozurumb (2013) [48], Obademi (2014) [49]. However the result contradicts same similar research conducted within the country like that by Abdulsalam \& Ibrahim (2013) [50] where they found that credits to private, government expenditure and interest rate spread exert negative influence on growth in the long run.

Accordingly, the findings agree with other research findings outside Nigeria such as Nikola \& Valev (2008) [51] who carried out a research covering 74 countries during the period 1990 to 2005. His finding shows that the availability of long-term credit is particularly important, as economic growth is faster in countries where the banking system extends more long-term credits. Conversely, the study contradicts the finding from research outside Nigeria by Zaghdoudi \& Soltani (2013) [52] who examine the influence of intermediation on the economic growth in 10 countries in the MENA region over the period 1990-2009 using a method of GMM estimation. The results indicate that when the variables of banking intermediation increase, economic growth decreases.

\section{Conclusion and Recommendation}

The study shows that bank credit variables viz: total bank credits to production sector (CPS), total bank credits to general commerce sector (CGCS) and total bank credits to services sector have a positive effect on the economic growth of Nigeria. It also shows that a long-run relationship between the variable exists. The result suggests that, the credits to services sector that is usually considered as the less-preferred sector compared to production sector contribute more to the economic growth than production sector. This, as earlier highlighted, might be due to the infrastructure decay in the country which affected the production of goods in the sector. The researcher therefore, recommends that the banks' regulatory bodies like central bank of Nigeria and the Nigeria deposit insurance corporation should develop policies that will encourage banks to extend more credits to the services sector and re-examine what should be called preferred sector by including sectors that contribute to the economic growth based on empirical evidence rather than looking at the activities provided by the sector. In this way more credit would be allocated to the sectors with higher contribution to the GDP with consequent effect on the economic growth. 


\section{Acknowledgements}

I wish to acknowledge Dr. S. A. S. Aruwa (Associate Professor of Accounting) who is currently the Dean of Faculty of Administration, Nasarawa State University, Keffi, Nigeria, for his immense contribution to the success of this study. I wish to further appreciate the support of Akwe, James Ayuba of Nigerian Securities and Exchange Commission.

\section{References}

[1] Cetorelli, N. and Gambera, M. (2001) Banking Market Structure, Financial Dependence, and Growth: International Evidence from Industry Data. Journal of Finance, 2, 617-648. http://dx.doi.org/10.1111/0022-1082.00339

[2] McKinnon, R. (1973) Money and Capital in Economic Development. The Brookings Institute, Washington DC.

[3] King, R.G. and Levine, R. (1993) Finance and Growth: Schumpeter Might Be Right. Quarterly Journal of Economics, 108, 717-737. http://dx.doi.org/10.2307/2118406

[4] Ndebbio, J.E.U. (2004) The Impact of Financial Deepening on Growth: A Study of Selected Sub-Saharan African Countries. NDIC Quarterly, 1.

[5] Adelman, I. and Morris, C.T. (1967) Society, Politics and Economic Development: A Quantitative Approach. John Hopkin, Baltimore.

[6] Goldsmith, R.N. (1969) Financial Structure and Development. Yale University Press, New Haven.

[7] Patrick, H.T. (1966) Financial Development and Economic Growth in Underdeveloped Countries. Economic Development and Cultural Change, 14, 174-189. http://dx.doi.org/10.1086/450153

[8] King, R.G. and Levine, R. (1993) Finance and Growth: Schumpeter Might Be Right. Quarterly Journal of Economics, 108, 717-738. http://dx.doi.org/10.2307/2118406

[9] Rioja, F. and Valev, N. (2003) Does One Size Fit All? A Re-Examination of the Finance and Growth Relationship. Social Science Research Network.

[10] Demetriades, P. and Hussein, K. (1996) Financial Development and Economic Growth: Cointegration and Causality Tests for 16 Countries, Journal of Development Economics, 51, 387-411. http://dx.doi.org/10.1016/S0304-3878(96)00421-X

[11] Demetriades, P. and Andrianova, S. (2004) Finance and Growth: What We Know and What We Need to Know. University of Leicester, Leicester.

[12] Ghirmay, T. (2004) Financial Development and Economic Growth in Sub-Saharan African Countries: Evidence from Time Series Analysis. African Development Bank, Abidjan.

[13] McKinnon, R. (1973) Money and Capital in Economic Development. The Brookings Institute, Washington DC.

[14] Shaw, E.S. (1973) Financial Deepening in Economic Development. Oxford University Press, Oxford.

[15] Akpan, I. (2004) Fundamentals of Finance. 2nd Edition, Nelgrafik Nig. Ltd., Uyo.

[16] Schumpeter, J.A. (1911) The Theory of Economic Development. Harvard University Press, Cambridge.

[17] Shaw, E.S. and Gurley, J.G. (1955) Financial Aspect of the Economic Development. The American Economic Review, 45, 515-538.

[18] Levine, R. and Zervos, S. (1996) Stock Market Development and Long-Run Growth. The World Bank Economic Review, 10, 323-339. http://dx.doi.org/10.1093/wber/10.2.323

[19] Schumpeter, J.A. (1952) The Theory of Economic Development. Harvard University Press, Cambridge.

[20] Allen, D.S. and Ndikumana, L. (1998) Financial Intermediation and Economic Growth in South Africa. Working Paper Series, Federal Reserve Bank, St. Louis.

[21] Ayadi, O.F., Adegbite, E.O. and Ayadi, F.S. (2008) Structural Adjustment, Financial Sector Development and Economic Prosperity in Nigeria. International Journal of Finance and Economics, 15, 318-331.

[22] Hesse, H. (2007) Financial Intermediation in the Pre-Consolidated Banking Sector in Nigeria. World Bank Policy Research Working Paper 4267, Washington DC.

[23] Robinson, J. (1952) The Generalisation of the General Theory, in the Rate of Interest, and Other Essays. 2nd Edition, Macmillan, London.

[24] Patrick, H.T. (1966) Financial Development and Economic Growth in Underdeveloped Countries. Economic Development and Cultural Change, 14, 174-189. http://dx.doi.org/10.1086/450153

[25] Esso, J.L. (2010) Re-Examining the Finance Growth Nexus: Structural Break, Threshold Cointegration and Causality Evidence from the Ecowas. Journal of Economic Development, 35, 57-79. 
[26] Lucas, R. (1988) On the Mechanics of Economic Development. Journal of Monetary Economics, 22, 3-42. http://dx.doi.org/10.1016/0304-3932(88)90168-7

[27] Blum, D., Federmair, K., Fink, G. and Haiss, P. (2002) The Financial-Real Sector Nexus: Theory and Empirical Evidence. IEF Working Paper No. 43.

[28] Greenwood, J. and Jovanovic, B. (1990) Financial Development, Growth and the Distribution of Income. Journal of Political Economy, 98, 1076-1107. http://dx.doi.org/10.1086/261720

[29] Bencivenga, V.R. and Smith, B.D. (1991) Financial Intermediation and Endogenous Growth. Review of Economic Studies, 58, 195-209. http://dx.doi.org/10.2307/2297964

[30] Pagano, M. (1993) Financial Markets and Growth: An Overview. European Economic Review, 37, $613-622$. http://dx.doi.org/10.1016/0014-2921(93)90051-B

[31] Azege, M. (2004) The Impact of Financial Intermediation on Economic Growth: The Nigerian Perspective. Lagos State University, Ojo.

[32] Agu, C.C. and Chukwu, J.O. (2008) Toda and Yamamoto Causality Tests between "Bank Based” Financial Deepening and Economic Growth in Nigeria. European Journal of Social Science, 7, 189-198.

[33] Fadare, S.O. (2010) Recent Banking Sector Reforms and Economic Growth in Nigeria. Middle Eastern Finance and Economics, 146-160.

[34] Balogun, E.D. (2007) A Review of Soludo’s Perspective of Banking Sector Reforms in Nigeria. http://mpra.ub.uni-muenchen.de/3803/

[35] Al-Khatib, K., Naser, K. and Jamal, A. (1999) Islamic Banking: A Study of Customer Satisfaction and Preferences in Jordan. International Journal of Bank Marketing, 17, 135-151. http://dx.doi.org/10.1108/02652329910269275

[36] Femi Kayode, O.F., Edun, A.T. and Obamuyi, T.M. (2010) Bank Lending, Economic Growth and the Performance of the Manufacturing Sector in Nigeria.

[37] Chang, P.C., Jia, C.X. and Wang, Z.C. (2010) Bank Fund Reallocation and Economic Growth: Evidence from China. Journal of Banking \& Finance, 34, 2753-2766. http://dx.doi.org/10.1016/j.jbankfin.2010.05.015

[38] Demetriades, O.P. and James, G.A. (2011) Finance and Growth in Africa: The Broken Link. Economic Letters, 113, 263-265. http://dx.doi.org/10.1016/j.econlet.2011.08.007

[39] Estrada, G., Park, D. and Kamayandi, A. (2010) Financial Development and Economic Growth in Asia. ADB Working Paper No 233, Metro Manila.

[40] Kumar, R.R. (2011) Do Remottances, Exports and Financial Development Matter for Economic Growth? A Case Study of Pakistan Using Bounds Approach. Journal of International Academic Research, 11.

[41] Oluitan, R.O. (2012) Bank Credit and Economic Growth: Evidence from Nigeria. International Business and Management, 5, 102-110.

[42] Zhang, J., Wang, L. and Wang, S.S. (2012) Financial Development and Economic Growth: Recent Evidence from China. Journal of Comparative Economics, 40, 393-412. http://dx.doi.org/10.1016/j.jce.2012.01.001

[43] Emmanuel, O.O. and Adegboyega, E. (2014) Banks and Economic Growth in Nigeria: A Re-Examination of the Financial Repression Hypothesis. American Journal of Business and Management, 3, 1-9.

[44] Akaike, H. (1969) Statistical Predictor Identification. Annals of the Institute of Statistical Mathematics, 22, $207-217$.

[45] Schwarz, G. (1978) Estimating the Dimension of a Model. Annals of Statistics, 6, 461-464. http://dx.doi.org/10.1214/aos/1176344136

[46] Akaike, H. (1987) Factor Analysis and AIC. Psychometrika, 52, 317-332. http://dx.doi.org/10.1007/BF02294359

[47] Johansen, S. (1988) Statistical Analysis of Cointegrating Vectors. Journal of Economic Dynamics and Control, 12, 231-254. http://dx.doi.org/10.1016/0165-1889(88)90041-3

[48] Onuorah, A.C. and Ozurumba, B.A. (2013) Bank Credits: An Aid to Economic Growth in Nigeria. Information and Knowledge Management, 3, 41-51.

[49] Obademi, O.E. and Elumaro, A. (2014) Banks and Economic Growth in Nigeria: A Re-Examination of the Financial Repression Hypothesis. American Journal of Business and Management, 3, 1-9.

[50] Abdulsalam, A. and Ibrahim, M.G. (2013) Impact of Banking Sector Development on Economic Growth: Another Look at the Evidence from Nigeria. Journal of Business Management \& Social Sciences Research (JBM \& SSR), 2.

[51] Nikola, T. and Valev, N.T. (2008) The Maturity Structure of Bank Credit: Determinants and Effects on Economic Growth. Andrew Young School of Policy Studies Research Paper Series No. 08-12.

[52] Zaghdoudi, T., Ochi, A. and Soltani, H. (2013) Banking Intermediation and Economic Growth: Some Evidence from MENA Countries. Advances in Management \& Applied Economics, 3, 51-57. 